\title{
Slag Evaluation to Reduce Energy Consumption and EAF Electrical Instability
}

\author{
Deisi Vieira ${ }^{*}$, Rodolfo Arnaldo Montecinos de Almeida ${ }^{a}$,Wagner Viana Bielefeldt ${ }^{a}$,
}

\author{
Antônio Cezar Faria Vilela ${ }^{a}$
}

\author{
${ }^{a}$ Steelmaking Laboratory - LaSid, Programa de Pós-Graduação em Engenharia de Minas, Metalúrgica \\ e de Materiais - PPGE3M, Federal University of Rio Grande do Sul - UFRGS, Porto Alegre, RS, Brazil
}

Received: November 25, 2015; Revised: June 24, 2016; Accepted: August 10, 2016

\begin{abstract}
In steel mills that operate with electric arc furnaces (EAF), it is interesting to ensure greater stability to the electric arc to aim at less distortion in the electrical system, with consequent reduction in electric power consumption. The slag foaming increases electric arc stability by reducing the total harmonic distortion (THD) between EAF phases. In this study, information about the chemical composition of the slag and electrical parameters of an EAF were collected. With the composition data, it was possible to determine the $\mathrm{FeO}$ and $\mathrm{MgO}$ content and basicity of the foamy slag which caused a reduction in THD and in electric power consumption. The effective viscosity of foaming slag was calculated and an increase in the effective viscosity provided a decrease in THD. A reduction of THD showed a decrease in the consumption of electric power in the EAF refining stage.
\end{abstract}

Keywords: Foamy slag; Electric arc stability; Electric power consumption of the EAF

\section{Introduction}

Harmonics are caused by non-linear loads that draw a non-sinusoidal current from a sinusoidal voltage source. An example of a harmonic producing load is electric arc furnaces. The sum of the harmonics contents can be represented by the total harmonic distortion (THD), as shown in Figure 1. Note that the graph peaks show that in scrap melting there is a strong intensity of voltage harmonics. On the other hand, in the refining stage, the stability increases significantly, because THD is reduced ${ }^{1}$.

The harmonics caused by the instability are higher in the first minutes of the melting process. The voltage and current profile at the start of scrap melting and after forming foamy slag is shown in Figure 2. Note a great reduction of harmonics, and a waveform closer to sinusoidal in shape ${ }^{2}$.

The slag foaming quality is an important factor to be studied in steel production in EAF process. The foamy slag contributes to reduce energy costs as it ensures that the heat from the liquid bath is not lost through the EAF walls. Furthermore, if a good slag foaming is ensured, energy efficiency of the furnace increases. Also, there is a reduction in the vibrations, noise and electrode consumption. The turbulence generated during the melting creates large fluctuations, nonlinearity and instability of the electric arc current in the different phases. A good quality foaming slag covers the charge and makes a smooth uniform path for current through three electrodes ${ }^{3}$.

Researchers seek to develop useful models to control slag foaming in steelmaking processes and understand the influence of the chemical composition of the $\mathrm{slag}^{4}$. The

*e-mail: deisi.ivieira@gmail.com foaming index, or average time for a gas to cross the slag is obtained by the ratio between the slag foam height and the gas superficial velocity. Skupien and Gaskell ${ }^{5}$, developed a mathematical model that shows the strong relationship between the foaming index and the physical properties of the slag, such as viscosity, density and surface tension ${ }^{5}$. During EAF operation, the iron oxide $(\mathrm{FeO})$ in the slag is typically formed by iron oxidation when oxygen is injected into the molten metal. $\mathrm{FeO}$ is an important component in the slag and it has a significant effect in viscosity, foaming capacity, slag volume, productivity and energy consumption ${ }^{6}$. Aminorroaya $^{7}$ showed in his study that there is an optimum range of $\mathrm{FeO}$ to minimize energy consumption, Figure $3^{7}$.

The slag binary basicity is a ratio between the oxides $\% \mathrm{CaO}$ and $\% \mathrm{SiO}_{2}$. There are optimum points of basicity to achieve lower energy consumption, Figure 47.

The use of slag saturated in $\mathrm{MgO}$ is of great importance in the EAF operation since the saturation in this oxide assists the formation of the foamy slag, contributing to higher efficiency, lower energy cost, higher metal yield and longer life of the refractory ${ }^{8}$. The amount of $\mathrm{MgO}$ in the slag causes an increase in foaming index due to the higher amount of solid particles ${ }^{4}$.

This paper aims to relate the chemical composition and the effective viscosity to the electrical parameters of an electric arc furnace in order to reduce the instability of the electric arc itself and electric power consumption in the refining stage.

\section{Materials and Methods}

Data from 156 steel heats of a specific cold charge, produced during one year, were collected. The selected cold 


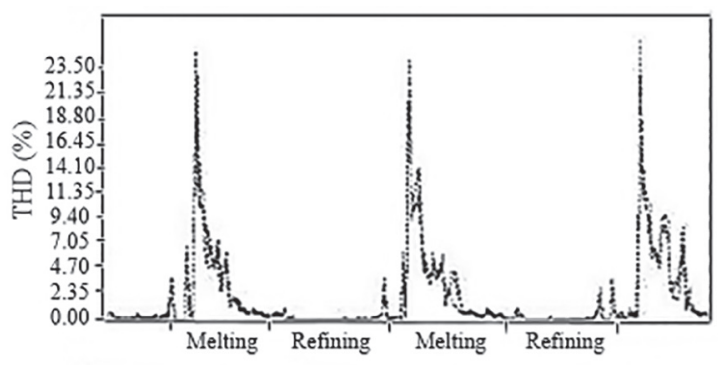

Figure 1: Total harmonic distortion during the melting and refining process ${ }^{1}$.

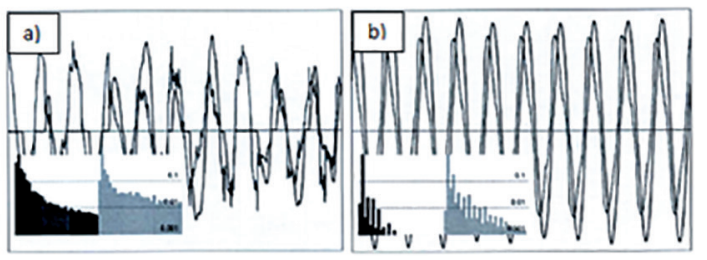

Figure 2: Shapes of sine waves, without foamy slag (a) and with foamy slag $(b)^{2}$.

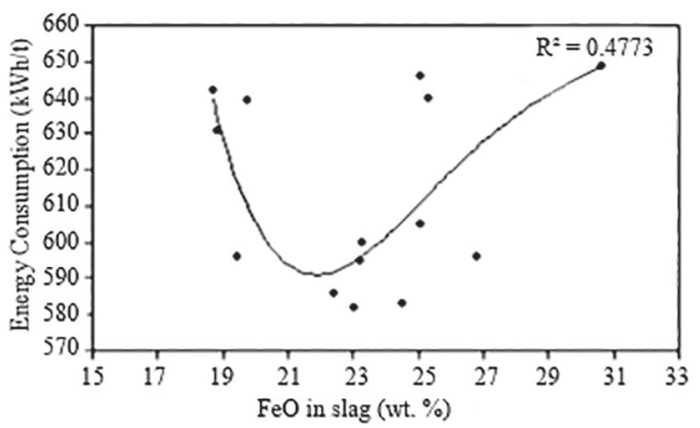

Figure 3: Relationship between the $\mathrm{FeO}$ content in slag and energy consumption ${ }^{7}$.

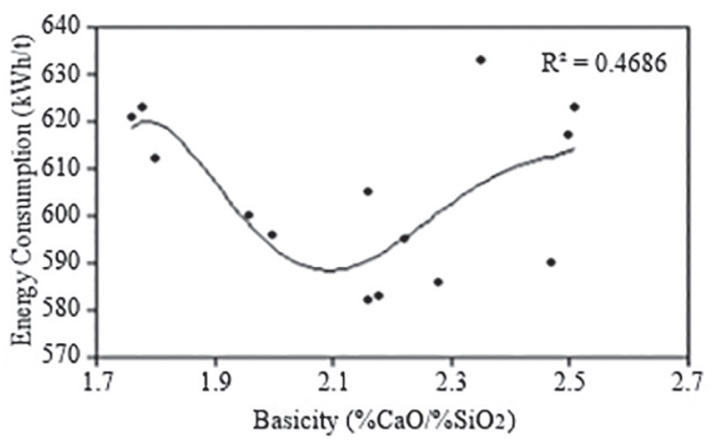

Figure 4: Relationship between basicity and energy consumption?

charge has a controlled chemical composition because it is used to produce a critical steel quality. Thus, the dispersion of both the chemical composition and the operational process variables were minimized so that the results by the high variability of parameters that are being considered in this study are minimized.
The analyzed electrical data were received directly from the electrical system of an EAF.

An analysis to evaluate the dispersion of "power on" (furnace time on) and "power off" (furnace time off) of the furnace was made. Voltage and total harmonic distortion per second of each phase were made available (three electrodes) during the heats; with this, the standard deviation of these data only in the refining interval could be calculated. Electric power consumption of the heats in this interval was also obtained. The voltage, total harmonic distortion and electric power consumption are factors that are directly related to the stability of the electric arc.

The chemical composition of the analyzed slag was obtained by the standard slag sample furnace practice, taken simultaneously with the steel during the refining period. In addition, the $\mathrm{FeO}, \mathrm{MgO}$ content and the basicity range were evaluated. The ranges that the chemical composition of FeO, $\mathrm{MgO}$ and basicity presented higher number of heats were compared to the electric power consumption. The physical properties of the slag were calculated, considering the temperature of $1600^{\circ} \mathrm{C}$. This temperature was chosen by the average value found during the sampling. The viscosity was calculated using the FactSage version 6.4 thermodynamic simulation software ${ }^{9}$, using melts database.

The properties, models and their equations are presented below:

Slag density (Mills and Keene's model $)^{10}$

$$
\rho=2460+0.18(\% \mathrm{FeO}+\% \mathrm{MnO})(1)
$$

$\rho=$ Slag density;

$\% \mathrm{FeO}=$ mass percent of iron oxide in the slag;

$\% \mathrm{MnO}=$ mass percent of manganese oxide in the slag.

Surface tension (Mills and Keene's model) ${ }^{10}-$

$$
\sigma=754,24-569.4\left(\frac{\% \mathrm{SiO}_{2}}{100}\right)-137.13\left(\frac{\% \mathrm{FeO}}{100}\right)
$$

$\sigma=$ surface tension;

$\% \mathrm{SiO}_{2}=$ mass percent of silica oxide in the slag;

$\% \mathrm{FeO}=$ mass percent of iron oxide in the slag.

Effective viscosity (Roscoe-Einstein's model) ${ }^{11}-$

$$
\eta_{e}=\eta(1-\tau \theta)^{-5 / 2}
$$

$\eta_{e}$ - Effective viscosity of the slag;

$\eta$ - Viscosity of the molten slag;

$\theta$ - Fraction precipitated solid phases;

$\tau$ - Solid interaction parameter (in dilute suspension of spheres with different sizes, the parameter is equal to the unit) ${ }^{11}$.

The main solid particles found were $(\mathrm{Mg}, \mathrm{Fe}) \mathrm{O}$ (magnesium-wustite) and $\mathrm{C}_{2} \mathrm{~S}\left(\mathrm{Ca}_{2} \mathrm{SiO}_{4}\right)$, according to the thermodynamic calculations. The effective slag viscosity values were compared to the THD, in order to evaluate the effect of foaming in the refining. 


\section{Results and Discussion}

The "power off" and "power on" were analyzed for all 156 heats, and were disregarded the heats that underwent a very long meltdown time due to any operation delay, to not influence the final results.

From all the analyzed heats, 70\% had a "power off" time of less than 4 minutes. In the "power on" case, most of the heats are distributed in a wide range with times lasting from 7 to 13 minutes. "Power off" time over 4 minutes and "power on" times less than 7 minutes and greater than 13 minutes were not considered for better correlation, resulting in 72 heats considered in this study.

The range of chemical composition $(\mathrm{MgO}, \mathrm{FeO}$ and basicity) of the heats with "power off" time less than 4 minutes and "power on" times more than 7 minutes and less than 13 minutes are in Table 1.

Table 1: Range of chemical composition of slag from the heats.

\begin{tabular}{lccc}
\hline & $\begin{array}{c}\mathrm{MgO} \\
(\mathrm{wt} . \%)\end{array}$ & $\begin{array}{c}\mathrm{FeO} \\
(\mathrm{wt} . \%)\end{array}$ & $\begin{array}{c}\text { Basicity } \\
\left(\% \mathrm{CaO} / \% \mathrm{SiO}_{2}\right)\end{array}$ \\
\hline $\begin{array}{l}\text { Chemical } \\
\text { composition range } \\
\text { from the heats } \\
\text { considered }\end{array}$ & $4.0-9.5$ & $16.0-40.0$ & $1.5-4.5$ \\
$\begin{array}{l}\text { Chemical } \\
\text { composition range } \\
\text { considered in this } \\
\text { study }\end{array}$ & $4.0-9.5$ & $25.0-35.5$ & $2.4-3.2$ \\
\hline
\end{tabular}

Table 1 shows that the $\mathrm{FeO}$ range considered in this study, between $25.0-35.0 \%$, represents $55 \%$ of the heats with "power off" time less than 4 minutes and "power on" times more than 7 minutes and less than 13 minutes. The basicity values between 2.4 and 3.2 represent $64 \%$ of the heats. For the ideal foaming, the slag has to be at an optimum basicity value. If the slag shows low basicity, it will be very fluid, if it is extremely basic, there will be an excess of solid particles hardening the slag and making it unlikely to foam ${ }^{12}$.

The energy consumed in the refining for the ranges that the chemical composition of $\mathrm{FeO}, \mathrm{MgO}$ and basicity presented higher number of heats, is shown in Tables 2 and 3 .

Table 2: Extremes values obtained from electric power consumption for the main $\mathrm{FeO}$ ranges.

\begin{tabular}{lcc}
\hline $\begin{array}{l}\text { FeO Range } \\
(\text { wt.\%) }\end{array}$ & $\begin{array}{c}\text { Minimum Electric } \\
\text { Power Consumption } \\
\text { in Refining }(\mathrm{kWh} / \mathrm{t})\end{array}$ & $\begin{array}{c}\text { Maximum Electric } \\
\text { Power Consumption } \\
\text { in Refining }(\mathrm{kWh} / \mathrm{t})\end{array}$ \\
\hline $25.0-27.5$ & 42.46 & 108.14 \\
$27.5-30.0$ & 42.14 & 87.51 \\
$30.0-32.5$ & 62.79 & 114.09 \\
$32.5-35.0$ & 66.91 & 103.26 \\
\hline
\end{tabular}

Table 3: Extremes values obtained from electric power consumption for the main basicity ranges.

\begin{tabular}{lcc}
\hline $\begin{array}{l}\text { Basicity Range } \\
\left(\% \mathrm{CaO} / \% \mathrm{SiO}_{2}\right)\end{array}$ & $\begin{array}{c}\text { Minimum } \\
\text { Electric Power } \\
\text { Consumption in } \\
\text { Refining }(\mathrm{kWh} / \mathrm{t})\end{array}$ & $\begin{array}{c}\text { Maximum } \\
\text { Electric Power } \\
\text { Consumption in } \\
\text { Refining }(\mathrm{kWh} / \mathrm{t})\end{array}$ \\
\hline $2.4-2.6$ & 71.75 & 108.54 \\
$2.6-2.8$ & 69.02 & 97.59 \\
$2.8-3.0$ & 67.68 & 114.09 \\
$3.0-3.2$ & 67.08 & 94.24 \\
\hline
\end{tabular}

It can be said that the best results occurred for the range between 27.5 to $30 \%$ of $\mathrm{FeO}$, because it was found the lowest maximum and minimum points for energy consumption.

It can be observed that the basicity range that presented the best performance in terms of energy consumed during refining is between 3 and 3.2, with the lowest maximum energy consumption value of $94.24 \mathrm{kWh} / \mathrm{t}$, and the point of lower energy consumption of $67.08 \mathrm{kWh} / \mathrm{t}$. According to the study of Aminorroaya ${ }^{7}, \mathrm{FeO}$ ranges and ideal basicity values were found to promote efficient foaming where it reaches minimum energy consumption.

Basicity ranges that presented lower electric power consumption were selected and the influence of the $\mathrm{MgO}$ content in the electric power consumption was analyzed, Figure 5.

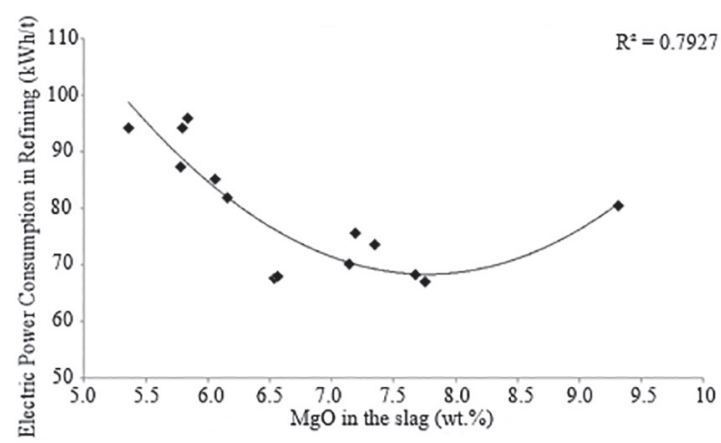

Figure 5: $\mathrm{MgO}$ content and electric power consumption.

Figure 5 shows that the minimum electric power consumption occur when $\mathrm{MgO}$ content is close to $7.5 \%$. In this content, the slag is saturated in $\mathrm{MgO}$ and having a beneficial effect in the foamy slag, according to Ito $^{4}$.

The behavior of the electric arc voltage and THD was evaluated during operation of the EAF, an example can be seen in Figure 6.

The refining stage is shown in Figure 6, showing that the stability of the arc increases with the presence of foaming slag, according to what Gandhare ${ }^{1}$ describes it in his study. The voltage standard deviation analyses by the THD standard deviation were made for each phase power of the EAF, Figure 7. 


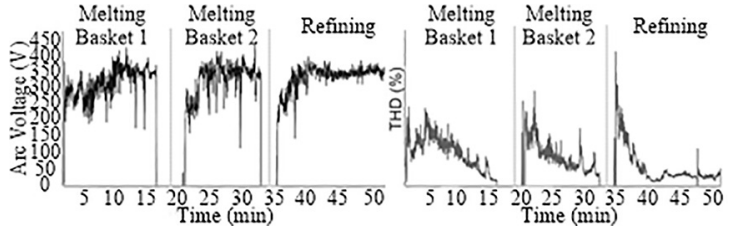

Figure 6: Arc voltage behavior (left) and THD (right) during a heat.

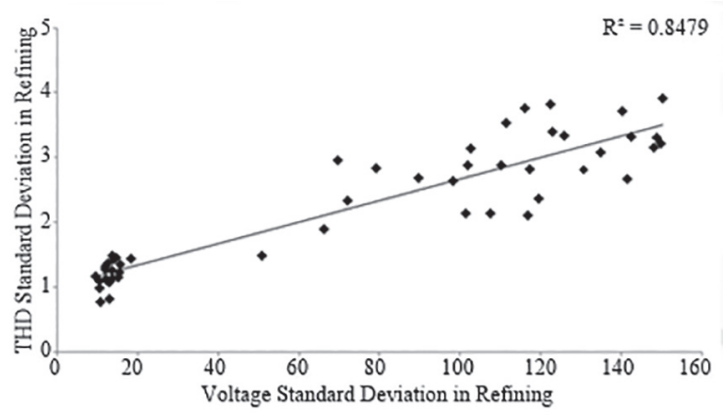

Figure 7: Relationship between the voltage standard deviation and the THD standard deviation.

Note the linear relationship between the voltage standard deviation and the THD standard deviation of the EAF. This is due to the fact that the higher the instability of the arc, the greater the voltage deviation, and therefore the greater the voltage harmonics variation. Figure 8 shows the harmonics standard deviation relating with the $\mathrm{FeO}$ content, considering the $\mathrm{FeO}$ content between 25 and $32 \%$ and basicity between 2.4 and 3.2 .

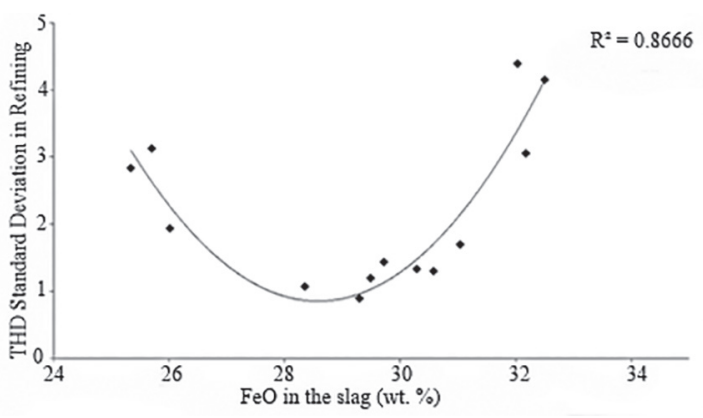

Figure 8: Relationship between the $\mathrm{FeO}$ content and the THD standard.

Figure 8 shows the point of minimal THD was found at $29 \%$ of $\mathrm{FeO}$. At higher basicity and lower $\mathrm{FeO}$ contents, the slag would be over-saturated in second phase particles, making it unlikely to foam. High basicity slags need high $\mathrm{FeO}$ content to be saturated in second phase particles and not over-saturated.

Heats with $\mathrm{FeO}$ content between 27.5 and $35 \%$, basicity between 2.6 to 3.2 were selected because they presented lower electric power consumption. Correlations between the THD standard deviation and the energy consumption can be seen in Figure 9, for the three phases of the EAF.

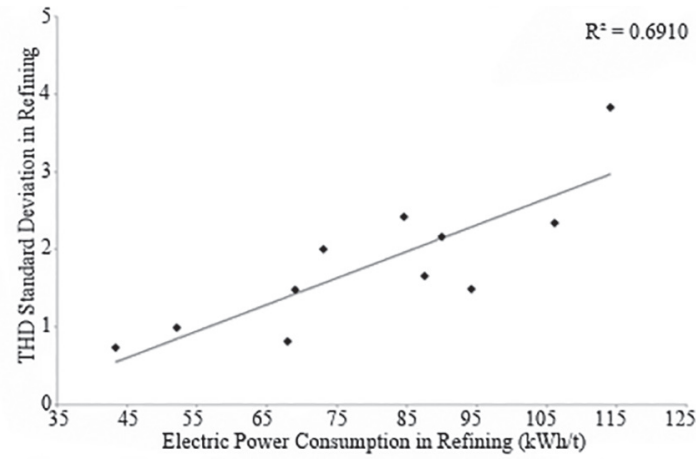

Figure 9: Electric power consumption in the refining and THD standard deviation.

It can be seen that the lower the THD standard deviation, lower the distortion generated by harmonics, therefore there is less electrical instability, and less electric power consumption.

The relationship between the calculated effective viscosity and THD standard deviation was performed, according to Figure 10. Heats with FeO content between 27.5 and 35\%, basicity between 2.6 to 3.2 were used.

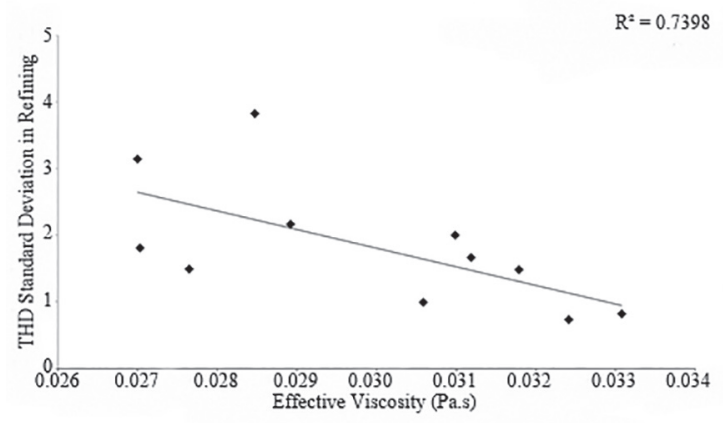

Figure 10: Relationship between effective viscosity calculated and THD standard deviation.

Figure 10 shows the expected trend, where THD decreases with the increase of the calculated effective viscosity. According to Skupien and Gaskell ${ }^{5}$ an increase of the effective viscosity promotes a better foaming slag and, consequently stabilizes the electric arc.

\section{Conclusions}

Considering the process conditions, the values of lower electric power consumption are found for the ranges of:

- FeO content between 27.5 and $30 \%$;

- Basicity between 3.0 and 3.2;

- $\mathrm{MgO}$ content between 7 and 8\%, for the heats that are within the optimum range of $\mathrm{FeO}$ and basicity.

Analyzing electrical data:

- The relationship between the voltage standard deviation and arc THD behaved linearly;

- The FeO content for a lower electric power consumption and lower THD was $29 \%$; 
- The THD and electric power consumption in refining had a positive correlation;

- The relationship between the effective viscosity and the THD behaved linearly with a negative correlation.

\section{Acknowledgment}

Deisi Vieira thanks Professor Wagner Bielefeldt, for the guidance and support, Professor Antônio Vilela for the opportunity, the Steelmaking Lab team at UFRGS, the Luiz Englert Foundation and $\mathrm{CNPq}$ for financial support.

\section{References}

1. Gandhare WZ, Lulekar DD. Analyzing Electric Power Quality in Arc Furnaces. In: Proceedings of International Conference on Renewable Energies and Power Quality (ICREPQ'07); 2007 Mar 28-30; Sevilla, Spain. 272.

2. Sedivy C, Krump R. Tools for foaming slag operation at EAF steelmaking. Archives of Metallurgy and Materials. 2008;53(2):405-409.

3. Dehkordi BM, Moallem M, Parsapour A. Predicting Foaming Slag Quality in Electric Arc Furnace Using Power Quality Indices and Fuzzy Method. IEEE Transactions on Instrumentation and Measurement. 2011;60(12):3845-3852.

4. Ito K, Fruehan RJ. Study on the foaming of $\mathrm{CaO}-\mathrm{SiO}_{2}-\mathrm{FeO}$ slags: Part I. Foaming parameters and experimental results. Metallurgical and Materials Transactions B. 1989;(4):515-521.
5. Skupien D, Gaskell DR. The surface tensions and foaming behavior of melts in the system $\mathrm{CaO}-\mathrm{FeO}-\mathrm{SiO}_{2}$. Metallurgical and Materials Transactions B. 2000;31(5):921-925.

6. Luz AP, Ávila TA, Bonadia P, Pandolfelli VC. Slag Foaming: Fundamentals, Experimental Evaluation and Application in the Steelmaking Industry. Refractories World Forum. 2011;3(2):91-98.

7. Aminorroaya-Yamini S, Edris H. The Effect of Foamy Slag in the Electric Arc Furnaces on Electric Energy Consumption. In: Proceedings of $7^{\text {th }}$ European Electric Steelmaking Conference; 2002 May 26-29; Venice, Italy. p. 2447-2456.

8. Bennett J, Kwong KS. Thermodynamic Studies of MgO Saturated EAF Slag. Ironmaking \& Steelmaking. 2010;37(7):529-535.

9. Paulino MAS, Klug JL, Bielefeldt WW, Vilela ACF, Heck N. Obtenção de Escória Espumante em Forno Elétrico a Arco: Determinação das Composições para o Sistema CaO-SiO2MgO-FeO. In: 45º Seminário de Aciaria - Internacional; 2014 May 25-28; Porto Alegre, Brazil.

10. Mills KC, Keene BJ. Physical Properties of BOS Slag. International Materials Reviews. 1987;32(1):1-120.

11. Roscoe R. Viscosity of Suspensions of Rigid Spheres. British Journal of Applied Physics. 1952;3(8):267-269.

12. Pretorius EB, Carlisle RC. Foamy slag fundamentals and their practical application to electric furnace steelmaking. In: $16^{\text {th }}$ Process Technology Conference Proceedings; 1998 Nov 15-18; New Orleans, USA. 